\title{
Regional patterns in prevalence of principal external diseases of dab Limanda limanda in the North Sea and adjacent areas 1992-1997
}

\author{
Volkert Dethlefsen ${ }^{1, *}$, Thomas Lang ${ }^{1}$, Peter Köves ${ }^{2}$ \\ ${ }^{1}$ Bundesforschungsanstalt für Fischerei, Institut für Fischereiökologie, Außenstelle Cuxhaven, Deichstraße 12, \\ 27472 Cuxhaven, Germany \\ ${ }^{2}$ Brahmstraße 48, 27476 Cuxhaven, Germany
}

\begin{abstract}
The prevalence and spatial distribution of major diseases of dab Limanda limanda in the North Sea and adjacent areas were studied in the summers 1992 to 1997. Areas covered were the North Sea, Irish Sea, northern and northeastern British Waters and the English Channel. The diseases studied were lymphocystis, epidermal hyperplasia/papilloma and skin ulceration. To standardise data, results were analysed for females $>15 \mathrm{~cm}$ ( $>3 \mathrm{yr}$ old). Data were subjected to median polish, and additive, extended and additive plus multiplicative models were applied to best account for effects of region and year. Annual differences in disease prevalence were low whilst differences between areas were pronounced. For lymphocystis higher prevalence was observed in the northwestern sector of the North Sea, at the northern tip of Scotland and in an area south of Iceland. Prevalence was low in the Irish Sea, the English Channel and the southern North Sea, and intermediate in the German Bight. For epidermal hyperplasia/papilloma, levels were low at Icelandic stations, in the northern Irish Sea, in the southern North Sea and the English Channel, whilst levels were high in the northwestern part of the North Sea and the German Bight. Elevated levels of skin ulceration were found on the Dogger, at 1 station in the Irish Sea (off Sellafield) and at 1 station to the south of Iceland. Lower levels were detected west of Iceland. Prevalence in all other areas was intermediate. It is concluded that a detailed analysis of available data on disease prevalence and putative causative factors is desirable and, given the good availability of data, would be a promising step forward toward elucidating possible cause and effect relationships between diseases and anthropogenic factors.
\end{abstract}

KEY WORDS: Lymphocystis · Skin ulceration · Epidermal papilloma/hyperplasia $\cdot$ Dab $\cdot$ Limanda limanda $\cdot$ Regional distribution $\cdot$ Prevalence rates $\cdot$ North Sea and adjacent areas

Resale or republication not permitted without written consent of the publisher

\section{INTRODUCTION}

From a report by Watermann \& Kranz (1992) it becomes obvious that the history of the occurrence of fish diseases in the North Sea is much longer than the period of their scientific description. Although McIntosh (1884) mentioned for British and German estuaries as well as for Scottish coastal waters that lymphocystis was very common in flounder Platichthys flesus, plaice Pleuronectes platessa and sole Solea solea, it was not until the 1920s that Johnstone (1922) and Schäperclaus (1927) issued reports on the occurrence

*E-mail: v.dethlefsen@t-online.de of obvious external signs of fish diseases from certain areas of the North Sea. Diseases of dab in the North Sea gained increasing attention after 1980, when several authors started systematic studies to quantify diseases of this ecologically important flatfish (Möller 1981, Bucke et al. 1983a,b, Dethlefsen 1984, Mellergaard \& Nielsen 1984, Vethaak 1985, van Banning 1987, McVicar et al. 1988). This upsurge of scientific interest was fuelled by a debate about whether elevated disease prevalence was related to pollution (Dethlefsen 1980, 1984, 1985, 1986, Dethlefsen et al. 1987). A major controversy centred around the question whether the dumping of wastes from titanium dioxide production was related to high levels of epi- 
Table 1. Limanda limanda. Results of published studies of diseases of dab. No. invest.: numbers of dab investigated; \% Ly: percentage lymphocystic; \% Ep pap: percentage epidermal papilloma; \% Ulc: percentage ulcerations; ni: not investigated

\begin{tabular}{|c|c|c|c|c|c|c|c|c|}
\hline Area & Region & Year & $\begin{array}{l}\text { Month of } \\
\text { season }\end{array}$ & $\begin{array}{l}\text { No. } \\
\text { invest. }\end{array}$ & $\%$ Ly & \% Ер рар & $\%$ Ulc & Source \\
\hline North Sea & $\begin{array}{l}\text { Total North } \\
\text { Sea and } \\
\text { Kattegat }\end{array}$ & $1977-1978$ & II, VIII, X & 18946 & $0.2-2.5$ & $\begin{array}{c}0.6 \\
\text { (only on } \\
\text { Dogger) }\end{array}$ & $2.3-9.6$ & Möller (1979) \\
\hline North Sea & Kattegat & 1980 & VIII & 3187 & $0.1-0.6$ & $0.1-0.3$ & $0.6-2.9$ & Möller (1981) \\
\hline North Sea & $\begin{array}{l}\text { Southern } \\
\text { North Sea }\end{array}$ & 1981-1985 & $\begin{array}{l}\text { Spring- } \\
\text { Autumn }\end{array}$ & $\begin{array}{r}16316 \\
5239\end{array}$ & $\begin{array}{l}1.7-4.1 \\
0.5-2.5\end{array}$ & $\begin{array}{r}0.8-4.9 \\
0-1.4\end{array}$ & $\begin{array}{l}0.3-1.3 \\
0.8-3.2\end{array}$ & van Banning (1987) \\
\hline North Sea & $\begin{array}{l}\text { German } \\
\text { Bight }\end{array}$ & 1981-1989 & $\mathrm{I}, \mathrm{V}, \mathrm{VI}$ & 41100 & $1.0-13.0$ & $1.0-9.5$ & $0-3.0$ & Dethlefsen (1990) \\
\hline $\begin{array}{l}\text { Southern } \\
\text { North Sea }\end{array}$ & $\begin{array}{l}\text { Dutch } \\
\text { coastal waters }\end{array}$ & 1986-1988 & Spring & 5942 & 5.1 & 4.7 & 0.8 & $\begin{array}{l}\text { Vethaak \& } \\
\text { van der Meer (1991) }\end{array}$ \\
\hline $\begin{array}{l}\text { Southern } \\
\text { North Sea }\end{array}$ & $\begin{array}{l}\text { German } \\
\text { Bight }\end{array}$ & 1991 & III & 7565 & $9.8-11.9$ & 6.2 & 1.7 & Vethaak et al. (1992) \\
\hline $\begin{array}{l}\text { Southern } \\
\text { North Sea }\end{array}$ & $\begin{array}{l}\text { Thames } \\
\text { Estuary }\end{array}$ & 1980 & VI, V, VI & 363 & 0 & ni & 1.4 & Bucke et al. (1983a) \\
\hline $\begin{array}{l}\text { English } \\
\text { Channel }\end{array}$ & Rye Bay & 1980 & VI, V, VI & 983 & 0.2 & ni & 1.6 & Bucke et al. (1983a) \\
\hline North Sea & $\begin{array}{l}\text { German } \\
\text { Bight }\end{array}$ & 1983-1992 & $\mathrm{V}$ & 13135 & $4.5-12.8$ & $1.4-9.4$ & $0.5-9$ & $\begin{array}{l}\text { Mellergaard \& } \\
\text { Nielsen (1997) }\end{array}$ \\
\hline North Sea & Horns Riff & 1983-1992 & $\mathrm{V}$ & 9384 & $3.0-14.9$ & $0.9-7.9$ & $0.2-2.2$ & $\begin{array}{l}\text { Mellergaard \& } \\
\text { Nielsen (1997) }\end{array}$ \\
\hline North Sea & Skagerrak & $1983-1993$ & $\mathrm{~V}$ & 7763 & $0.0-3.05$ & $0.0-1.3$ & $0.2-0.7$ & $\begin{array}{l}\text { Mellergaard \& } \\
\text { Nielsen (1997) }\end{array}$ \\
\hline $\begin{array}{l}\text { Scottish } \\
\text { East Coast }\end{array}$ & $\begin{array}{l}\text { Off Firth of } \\
\text { Forth }\end{array}$ & 1987 & $\mathrm{~V}, \mathrm{VI}$ & 3237 & $1.2-14.1$ & $0.0-3.5$ & $0.0-4.1$ & $\begin{array}{l}\text { McVicar et al. } \\
(1988)\end{array}$ \\
\hline $\begin{array}{l}\text { Northeast } \\
\text { Irish Sea }\end{array}$ & $\begin{array}{l}\text { Liverpool } \\
\text { Bay }\end{array}$ & 1982 & IV & 3769 & 1.5 & 1.1 & 1.4 & Bucke et al. (1983b) \\
\hline $\begin{array}{l}\text { Northeast } \\
\text { Irish Sea }\end{array}$ & $\begin{array}{l}\text { Firth of } \\
\text { Solvay }\end{array}$ & 1971 & V, VI, IX & 2601 & $1.5-1.6$ & ni & $1.7-4.7$ & Perkins et al. (1972) \\
\hline $\begin{array}{l}\text { Northeast } \\
\text { Irish Sea }\end{array}$ & $\begin{array}{l}\text { Liverpool } \\
\text { Bay, More- } \\
\text { cambe Bay }\end{array}$ & 1972 & IV & 936 & 1.1 & ni & $1.0-1.5$ & $\begin{array}{l}\text { Shelton \& } \\
\text { Wilson (1973) }\end{array}$ \\
\hline
\end{tabular}

dermal hyperplasia/papilloma of dab in German, Dutch and Belgium dumping areas (Dethlefsen 1986, Vethaak \& van der Meer 1991).

In the wake of this debate a number of ICES (International Council for the Exploration of the Sea) member countries launched programmes for the systematic collection of scientific data on the occurrence and abundance of fish diseases within their areas of interest. As can be seen in Table 1, various nations, like The Netherlands, the United Kingdom and Denmark, performed fish disease studies which all covered different areas although with certain overlaps.

Despite the enormous research effort, questions as to the cause of elevated disease levels in certain areas remained largely unanswered. Since the complexity of ecosystem interactions obscured causal relationships in situ, many countries became disillusioned and terminated their long-term studies. Vethaak \& ap Rheinallt (1992) summarised results of fish disease studies published to that date and discussed their relevance in terms of the relationship between fish diseases and marine pollution. Their conclusion was that there are good examples of cause and effect relationships from the North Sea particularly in local areas with distinct sources of pollution. Dethlefsen (1988) stated that due to our limited knowledge on ecosystem interactions it is unrealistic to expect that aquatic science will in the near future be able to produce results that unequivocally document a connection between specific malfunctions and specific pollutants.

Nevertheless, Vethaak \& ap Rheinallt (1992) recommended the continuation of long-term studies to pro- 
vide baseline knowledge on the fluctuations of diseases of marine fish over time and space in order to serve as a basis for examining the relationship between disease and a complex mixture of environmental variables.

The geographically restricted studies mentioned in Table 1 did not cover the complete area of dab distribution, which according to Lundbek (1955) and Rühmer (1954) extends from the European west coast from the Bay of Biscay in the south to the Barents Sea in the north and from the Icelandic shelf to the western Baltic. ICES is presently collecting data from the sources mentioned above in order to combine these into one map characterising the regional distribution of dab and to establish time trends of its diseases.

In order to reduce variance in the fish disease diagnosis as identified by Dethlefsen et al. (1984) ICES initiated and performed workshops with the aim of standardising and calibrating techniques of fish disease studies (Dethlefsen et al. 1986, Anonymous 1989, Lang \& Mellergaard 1999).

Despite these attempts it can be assumed that differences in the intensity of individual studies cannot be avoided.

The purpose of this paper is to present information on the regional distribution of 3 major external diseases of dab on a wider regional scale than hitherto published, i.e. the North Sea, Irish Sea, English Channel, and Iceland and adjacent areas, gathered under the supervision of one experienced investigator during 6 consecutive cruises in the summers of 1992 to 1997.

\section{MATERIAL AND METHODS}

Sampling was carried out in the period between June 1992 and June 1997. Information on stations and areas covered is given in Fig. 1 and Table 2. Numbers of hauls, of dab investigated, and of males and females $>15 \mathrm{~cm}$ in the samples are shown in Table 2, size, and the location of the areas in Table 3. Bottom trawling was performed with the standard bottom trawl used in ICES fisheries monitoring (GOV, Grand Ouverture Verticale); catches were sorted according to species. Sub-samples of dab were randomly selected from total catches to obtain representative length distributions. Per haul approximately 100 dab of all sizes and sexes were subsequently measured, sexed and diagnosed for the occurrence of gross externally visible diseases. The diagnosis was carried out according to ICES recommendations (Dethlefsen et al. 1986, Anonymous 1989, Bucke et al. 1996). Although diseases were graded in terms of severity, for the purpose of this paper diseases are reported only as present or absent.

To avoid confounding of data by prevalence rates of different sexes we performed our analysis on females only. To reduce variability due to differences in length/ age relationships we excluded dab $<15 \mathrm{~cm}$ ( $>2$ to $3 \mathrm{yr}$ ) (Lozàn 1988, Rijnsdorp et al. 1992) from the analysis of regional distribution of diseases.

The diseases registered were:

Lymphocystis, a wide-spread viral infection occurring in freshwater and marine fish, is caused by an iridovirus and gross clinical signs are small grey-white or reddish nodules, each measuring up to $2 \mathrm{~mm}$ in diameter, occurring either singly or in clusters with a tumorous appearance on the body surface and fins. Single nodules are individual hypertrophied cells in the connective tissue (Hill 1984).

Epidermal hyperplasia/papilloma are whitish, opaque swellings of the epidermis on the trunk and fins, a few $\mathrm{mm}$ high and up to 30 or more $\mathrm{mm}$ in diameter. The disease is possibly virus-induced; adenovirus-like particles were observed in epidermal hyperplasia and papilloma (Watermann et al. 1987).

Acute stages of skin ulceration are rounded hemorrhagic centres often with white peripheries. Healing stages are partly open with white and brown pigmentation forming scarred tissues. Skin ulceration have been attributed to bacterial infections but can arise as a result of parasite infestation, scale loss, traumatic injuries and a variety of adverse environmental factors (Bucke et al. 1996). For this study acute and healing stages of skin ulceration are combined.

Statistics. To identify regional and spatial patterns a statistical model which is resistant against outliers was used. First a simple additive model for 2-way tables is fitted by using median polish (Tukey 1977). When residuals from a simple additive fit reveal systematic departures from additivity, a more complex model is considered. The additive plus multiplicative model contains an additive and a multiplicative term and represents a generalisation of the previous additive model. To fit the multiplicative term as many nonpositive values as possible have to be removed. Since zero prevalence was rare for either of the diseases during this study, this procedure was not found to be critical. To compare models the distribution of the respective residuals is considered. Based on model results for each year and each area, an average disease rate is calculated. The methods used are fully described in Emerson \& Wong (1985), which is Chapter 3 of Hoaglin et al. (1985).

Median polish. In our example the disease rates are entered into a 2-way table, rows representing areas and columns representing years. The median polish for an additive model of the form $y_{i j}=m+a_{i}+b_{j}+e_{i j}$, with constant term $m$ (where $y_{i j}=$ observed value in area $i$ and year $j_{i} a_{i}=$ area effect in area $i_{i} b_{j}=$ year effect in year $j_{i} e=$ random error term) is performed in the following steps. 

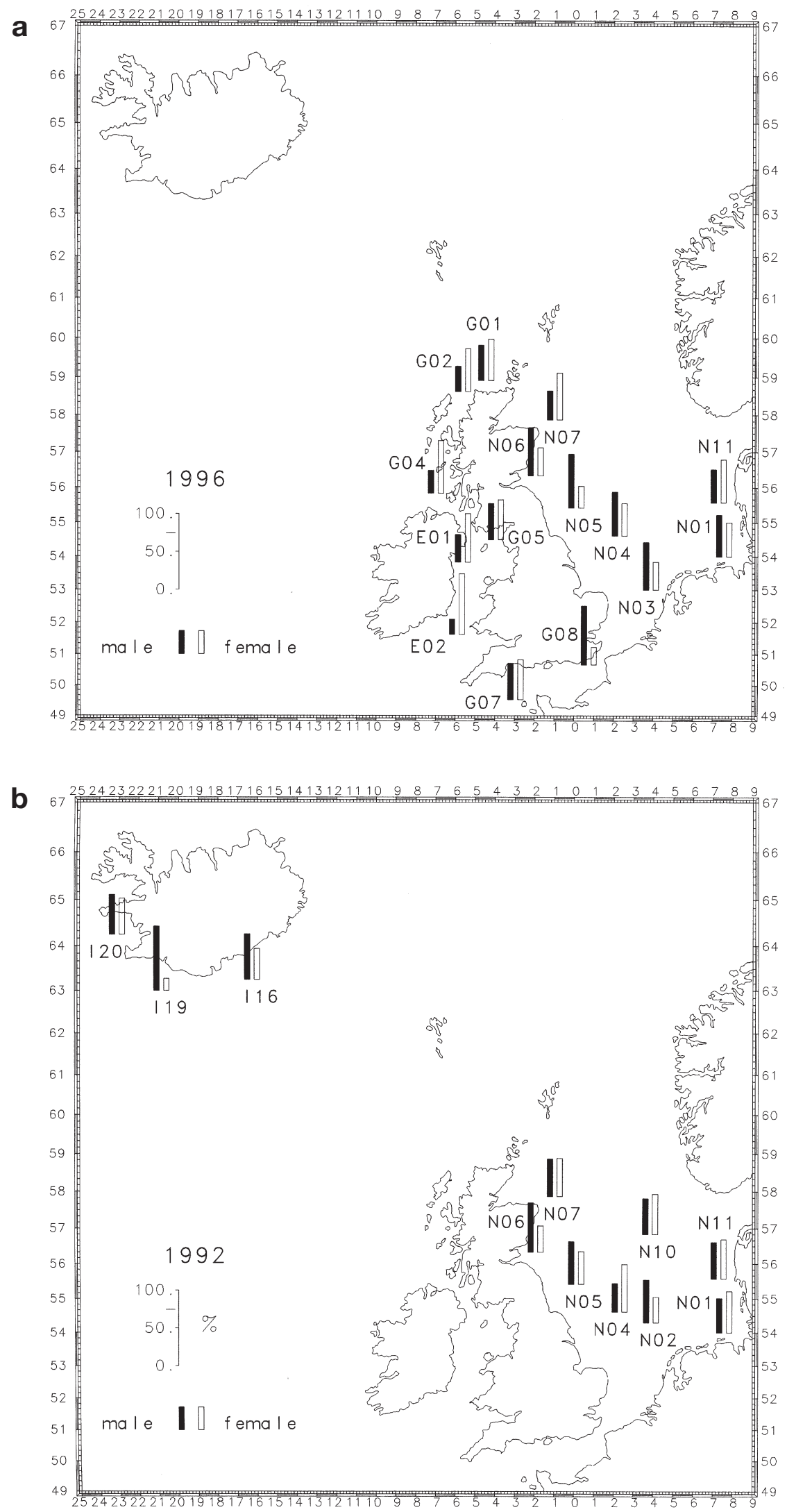

Fig. 1. Limanda limanda. Sex ratio (a) in 1992, (b) in 1996. Numbers on figure are station numbers 
Table 2. Dates and areas of sampling, no. of dab investigated, no. of males and no. of females in the respective areas

\begin{tabular}{|c|c|c|c|c|c|}
\hline Date & Stn & Area & $\begin{array}{l}\text { No. dab } \\
\text { invest. } \\
\text { all sizes }\end{array}$ & $\begin{array}{c}\text { No. } \\
\text { male } \\
>15 \mathrm{~cm}\end{array}$ & $\begin{array}{c}\text { No. } \\
\text { female } \\
>15 \mathrm{~cm}\end{array}$ \\
\hline June 1992 & N01 & North Sea & 745 & 312 & 376 \\
\hline June 1992 & N02 & North Sea & 1186 & 655 & 335 \\
\hline June 1992 & N04 & North Sea & 772 & 258 & 434 \\
\hline June.1992 & N05 & North Sea & 878 & 484 & 372 \\
\hline June 1992 & N06 & North Sea & 764 & 475 & 254 \\
\hline June 1992 & N07 & North Sea & 1015 & 488 & 495 \\
\hline June 1992 & I19 & Iceland & 334 & 277 & 52 \\
\hline June 1992 & $\mathrm{I} 20$ & Iceland & 622 & 322 & 293 \\
\hline July 1992 & I16 & Iceland & 352 & 210 & 142 \\
\hline July 1992 & N10 & North Sea & 1183 & 529 & 595 \\
\hline July 1992 & N11 & North Sea & 522 & 206 & 221 \\
\hline June 1993 & N01 & North Sea & 681 & 293 & 330 \\
\hline June 1993 & N04 & North Sea & 1033 & 426 & 571 \\
\hline June 1993 & N05 & North Sea & 841 & 526 & 304 \\
\hline June 1993 & N06 & North Sea & 856 & 538 & 301 \\
\hline June 1993 & N07 & North Sea & 400 & 199 & 194 \\
\hline July 1993 & $\mathrm{I} 16$ & Iceland & 544 & 385 & 157 \\
\hline July 1993 & N10 & North Sea & 1000 & 482 & 501 \\
\hline July 1993 & N11 & North Sea & 564 & 222 & 183 \\
\hline June 1994 & N01 & North Sea & 416 & 201 & 194 \\
\hline June 1994 & N04 & North Sea & 452 & 196 & 203 \\
\hline June 1994 & N06 & North Sea & 532 & 340 & 184 \\
\hline June 1994 & N07 & North Sea & 193 & 77 & 111 \\
\hline June 1994 & G04 & NW Scotland & 293 & 87 & 189 \\
\hline June 1994 & G05 & Irish Sea & 455 & 227 & 181 \\
\hline July 1994 & E02 & Irish Sea & 373 & 119 & 249 \\
\hline July 1994 & G07 & Engl. Channel & 207 & 40 & 65 \\
\hline July 1994 & G08 & Engl. Channel & 646 & 333 & 149 \\
\hline July 1994 & N03 & North Sea & 497 & 198 & 186 \\
\hline July 1994 & N11 & North Sea & 449 & 213 & 180 \\
\hline June 1995 & N01 & North Sea & 420 & 153 & 209 \\
\hline June 1995 & N11 & North Sea & 402 & 87 & 143 \\
\hline June 1995 & N04 & North Sea & 558 & 156 & 314 \\
\hline June 1995 & N05 & North Sea & 409 & 260 & 121 \\
\hline June 1995 & N06 & North Sea & 505 & 319 & 157 \\
\hline June 1995 & N07 & North Sea & 441 & 182 & 236 \\
\hline June 1995 & G02 & NW Scotland & 285 & 122 & 151 \\
\hline June 1995 & G04 & NW Scotland & 503 & 173 & 295 \\
\hline June 1995 & G05 & Irish Sea & 500 & 216 & 189 \\
\hline July 1995 & E02 & Irish Sea & 131 & 38 & 89 \\
\hline July 1995 & G07 & Engl. Channel & 264 & 81 & 159 \\
\hline July 1995 & G08 & Engl. Channel & 503 & 247 & 127 \\
\hline July 1995 & N03 & North Sea & 185 & 85 & 78 \\
\hline May 1996 & N01 & North Sea & 500 & 230 & 189 \\
\hline May 1996 & N11 & North Sea & 508 & 132 & 173 \\
\hline May 1996 & N04 & North Sea & 539 & 284 & 211 \\
\hline May 1996 & N05 & North Sea & 468 & 315 & 128 \\
\hline May 1996 & N06 & North Sea & 407 & 233 & 136 \\
\hline May 1996 & N07 & North Sea & 283 & 100 & 164 \\
\hline May 1996 & G01 & NW Scotland & 138 & 51 & 60 \\
\hline May 1996 & G02 & NW Scotland & 359 & 48 & 97 \\
\hline May 1996 & G04 & NW Scotland & 169 & 47 & 108 \\
\hline May 1996 & G05 & Irish Sea & 345 & 108 & 120 \\
\hline May 1996 & E01 & Irish Sea & 231 & 76 & 135 \\
\hline May 1996 & G07 & Engl. Channel & 148 & 65 & 71 \\
\hline May 1996 & G08 & Engl. Channel & 501 & 352 & 105 \\
\hline May 1996 & N03 & North Sea & 501 & 255 & 150 \\
\hline May 1997 & N01 & North Sea & 606 & 272 & 305 \\
\hline May 1997 & N03 & North Sea & 375 & 150 & 148 \\
\hline May 1997 & G08 & Engl. Channel & 529 & 339 & 136 \\
\hline May 1997 & G07 & Engl. Channel & 171 & 70 & 45 \\
\hline May 1997 & F05 & Engl. Channel & 357 & 135 & 219 \\
\hline May 1997 & N04 & North Sea & 501 & 221 & 234 \\
\hline June 1997 & N05 & North Sea & 502 & 354 & 127 \\
\hline June 1997 & N06 & North Sea & 500 & 291 & 206 \\
\hline June 1997 & N07 & North Sea & 404 & 171 & 209 \\
\hline June 1997 & N10 & North Sea & 397 & 126 & 243 \\
\hline June 1997 & N11 & North Sea & 408 & 183 & 137 \\
\hline
\end{tabular}

Table 3. Geographic boundaries of sampling areas

\begin{tabular}{|ccc|}
\hline Stn & Latitude & Longitude \\
\hline N01 & $54^{\circ} 15^{\prime} \mathrm{N}-54^{\circ} 25^{\prime} \mathrm{N}$ & $07^{\circ} 26^{\prime} \mathrm{E}-07^{\circ} 39^{\prime} \mathrm{E}$ \\
$\mathrm{N} 02$ & $54^{\circ} 18^{\prime} \mathrm{N}$ & $03^{\circ} 45^{\prime} \mathrm{E}^{\mathrm{a}}$ \\
$\mathrm{N} 03$ & $52^{\circ} 50^{\prime} \mathrm{N}-53^{\circ} 10^{\prime} \mathrm{N}$ & $03^{\circ} 30^{\prime} \mathrm{E}-04^{\circ} 10^{\prime} \mathrm{E}$ \\
$\mathrm{N} 04$ & $54^{\circ} 25^{\prime} \mathrm{N}-54^{\circ} 50^{\prime} \mathrm{N}$ & $02^{\circ} 00^{\prime} \mathrm{E}-02^{\circ} 31^{\prime} \mathrm{E}$ \\
$\mathrm{N} 05$ & $55^{\circ} 20^{\prime} \mathrm{N}-55^{\circ} 30^{\prime} \mathrm{N}$ & $00^{\circ} 00^{\prime} \mathrm{E}-00^{\circ} 25^{\prime} \mathrm{E}$ \\
$\mathrm{N} 06$ & $56^{\circ} 15^{\prime} \mathrm{N}-56^{\circ} 25^{\prime} \mathrm{N}$ & $01^{\circ} 50^{\prime} \mathrm{W}-02^{\circ} 10^{\prime} \mathrm{W}$ \\
$\mathrm{N} 07$ & $57^{\circ} 45^{\prime} \mathrm{N}-58^{\circ} 00^{\prime} \mathrm{N}$ & $00^{\circ} 44^{\prime} \mathrm{W}-01^{\circ} 20^{\prime} \mathrm{W}$ \\
$\mathrm{N} 10$ & $56^{\circ} 45^{\prime} \mathrm{N}-56^{\circ} 55^{\prime} \mathrm{N}$ & $03^{\circ} 30^{\prime} \mathrm{E}-03^{\circ} 55^{\prime} \mathrm{E}$ \\
$\mathrm{N} 11$ & $55^{\circ} 30^{\prime} \mathrm{N}-55^{\circ} 40^{\prime} \mathrm{N}$ & $07^{\circ} 00^{\prime} \mathrm{E}-07^{\circ} 30^{\prime} \mathrm{E}$ \\
I16 & $63^{\circ} 30^{\prime} \mathrm{N}-64^{\circ} 00^{\prime} \mathrm{N}$ & $16^{\circ} 10^{\prime} \mathrm{W}-16^{\circ} 40^{\prime} \mathrm{W}$ \\
$\mathrm{I} 19$ & $63^{\circ} 15^{\prime} \mathrm{N}-63^{\circ} 45^{\prime} \mathrm{N}$ & $20^{\circ} 45^{\prime} \mathrm{W}-21^{\circ} 15^{\prime} \mathrm{W}$ \\
I20 & $64^{\circ} 00^{\prime} \mathrm{N}-64^{\circ} 30^{\prime} \mathrm{N}$ & $22^{\circ} 15^{\prime} \mathrm{W}-22^{\circ} 45^{\prime} \mathrm{W}$ \\
G01 & $58^{\circ} 50^{\prime} \mathrm{N}-59^{\circ} 00^{\prime} \mathrm{N}$ & $04^{\circ} 30^{\prime} \mathrm{W}-05^{\circ} 00^{\prime} \mathrm{W}$ \\
G02 & $58^{\circ} 30^{\prime} \mathrm{N}-58^{\circ} 45^{\prime} \mathrm{N}$ & $05^{\circ} 50^{\prime} \mathrm{W}-06^{\circ} 00^{\prime} \mathrm{W}$ \\
G04 & $55^{\circ} 45^{\prime} \mathrm{N}-55^{\circ} 55^{\prime} \mathrm{N}$ & $07^{\circ} 00^{\prime} \mathrm{W}-07^{\circ} 15^{\prime} \mathrm{W}$ \\
G05 & $54^{\circ} 20^{\prime} \mathrm{N}-54^{\circ} 40^{\prime} \mathrm{N}$ & $03^{\circ} 50^{\prime} \mathrm{W}-04^{\circ} 10^{\prime} \mathrm{W}$ \\
G07 & $50^{\circ} 30^{\prime} \mathrm{N}-50^{\circ} 35^{\prime} \mathrm{N}$ & $02^{\circ} 40^{\prime} \mathrm{W}-03^{\circ} 20^{\prime} \mathrm{W}$ \\
G08 & $50^{\circ} 40^{\prime} \mathrm{N}-50^{\circ} 50^{\prime} \mathrm{N}$ & $00^{\circ} 30^{\prime} \mathrm{E}-00^{\circ} 50^{\prime} \mathrm{E}$ \\
E01 & $53^{\circ} 40^{\prime} \mathrm{N}-54^{\circ} 00^{\prime} \mathrm{N}$ & $05^{\circ} 40^{\prime} \mathrm{W}-05^{\circ} 50^{\prime} \mathrm{W}$ \\
E02 & $52^{\circ} 35^{\prime} \mathrm{N}-52^{\circ} 40^{\prime} \mathrm{N}$ & $06^{\circ} 00^{\prime} \mathrm{W}-06^{\circ} 05^{\prime} \mathrm{W}$ \\
F05 & $49^{\circ} 26^{\prime} \mathrm{N}-49^{\circ} 29^{\prime} \mathrm{N}$ & $00^{\circ} 38^{\prime} \mathrm{W}-00^{\circ} 50^{\prime} \mathrm{W}$ \\
${ }^{\mathrm{a}}$ Circle around this location $15 \mathrm{nautical} \mathrm{miles} \mathrm{in} \mathrm{diameter}$ \\
\hline
\end{tabular}

(1) For each row in the table row medians are calculated. These values are recorded in a column in the right-hand margin. Each entry of the table is replaced with the difference between that entry and the median for its row.

(2) The median for each column of the current table is calculated including the column of row medians. These values are recorded in a row at the lower margin of the table and each entry of the table is replaced with the difference between that entry and its associated column median. These steps comprise 1 full step of median polish. Results differ somewhat if the calculation is started with rows although results are generally similar. For this study we started with rows/areas since the difference between areas was larger than differences between years.

(3) For each row in the current table (including the row of column medians) the row median is subtracted for each of the current row entries and added to the corresponding entry at the right margin.

(4) The median value for each column is calculated (including the extra column at the right). This value is subtracted from each entry in this column and added to the corresponding entry at the row at the lower margin of the table. Now 2 full steps of median polish are completed.

(5) Steps 3 and 4 are repeated until further adjustments to row medians and column median are negligible.

(6) The final entry in the lower right corner is $m$. The area effects are the other entries at the right margin. The year effects are at the lower margin. The remain- 
ing entries in the original table are the residuals $e$ of the additive fit.

Extended model. To test for non-additive structures in the residuals $e$ these can be plotted against the comparison values $a_{i} b_{j} / m$. If this diagnostic plot reveals a slope $k$ (calculated by linear least squares or robust linear regression), which is different from zero, it is possible to extend the additive model by the equation $e_{i j}=k a_{i} b_{j}+r_{i j}$.

The extended model has the form $y_{i j}=m+a_{i}+b_{j}+$ $k a_{i} b_{j}+r_{i j}$.

The new residuals $r_{i j}$ can be repolished and the results be combined with those from the original median polish. Then the value of $k$ can be revised. This algorithm can be regarded as iterative.

The non-additive structure of the data can also be removed by a power transformation with the power $p=1-k$. If $p=0$, this recommends a log transformation of the original data.

Additive plus multiplicative model. A more general model to extract multiplicative structures from the residuals of the additive model is the additive plus multiplicative model $y_{i j}=m+a_{i}+b_{j}+k c_{i} d_{j}+e_{i j}$.

When $k=0$, this corresponds to the simple additive model. If $a=c$ and $b=d$, this is the extended model. There are 2 further versions: the column linear model $y_{i j}=m+a_{i}+b_{j}+k a_{i} d_{j}+e_{i j}$ and the row linear model $y_{i j}=m+a_{i}+b_{j}+k c_{i} b_{j}+e_{i j}$

These models can be considered if a plot of $c$ against $a$ or $d$ against $b$ reveals a straight line.

The additive plus multiplicative model is calculated by performing the following steps.

(1) Median polish is used to obtain the additive term. At this stage the residuals e should be explored via the diagnostic plot and it should considered whether to apply power transformation or an extended fit.

(2) To fit multiplicatively the residuals from the simple additive fit, sign changes are performed in rows and columns in order to reduce the number of negative entries.

(3) Remaining non-positive entries are replaced with a very small positive number (for instance $10^{-6}$ ).

(4) Logs are taken and the median polish is used to construct the fit $\log (\hat{u})=m^{\prime}+a^{\prime}+b^{\prime}$.

(5) Exponentials are taken to return to the scale of the original data and to obtain the fit $\hat{u}=k c^{\prime} d^{\prime}$, with $k$ as estimated in the extended model.

(6) After restoring signs to rows and columns whose signs were changed in Step 2, the equation $\hat{e}=k c_{i} d_{j}$, is obtained resulting in the additive plus multiplicative fit $y_{i j}=m+a_{i}+b_{j}+k c_{i} d_{j}$.

(7) Finally, median polish is applied to residuals ê to recenter the additive components of the fit at zero.

(8) Multiplicative components may be again calculated to further iterate the fit.

\section{RESULTS}

\section{Comparison of models}

The impact of the application of the additive, extended and additive plus multiplicative models on the size of the error term for each disease can be seen in Fig. 2. In all cases the application of the additive plus multiplicative model achieved the best reduction of the error variation, this effect being lowest for epidermal hyperplasia. Results are therefore presented based on the application of the additive plus multiplicative model.

a

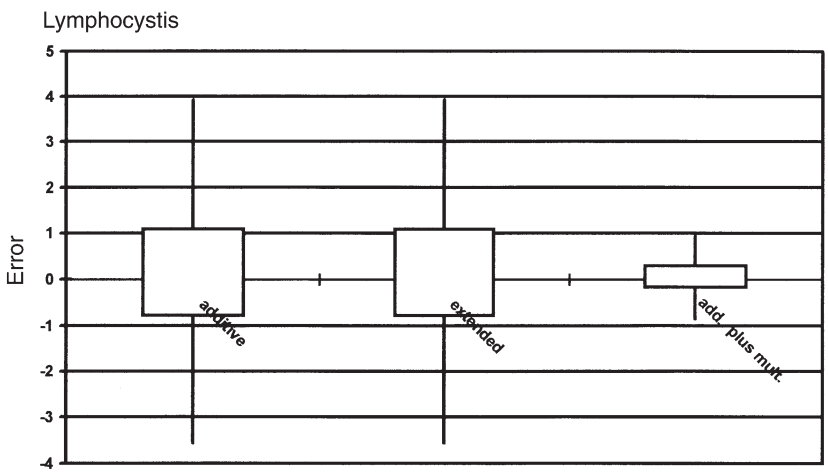

b Epidermal Papilloma

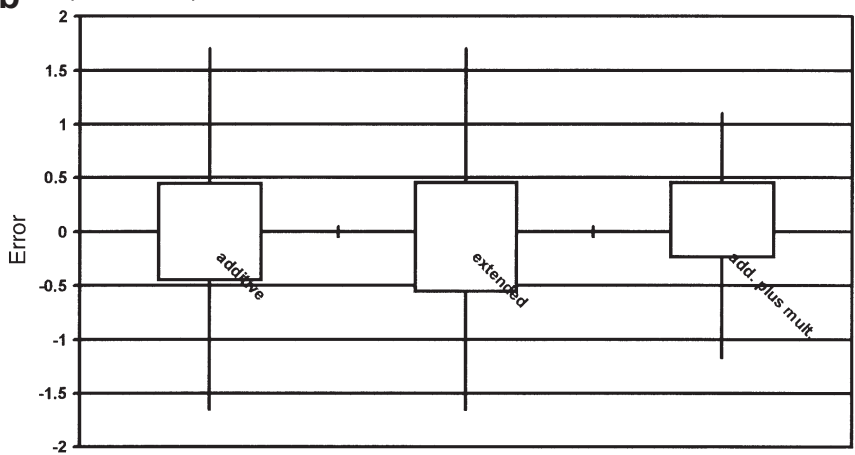

c

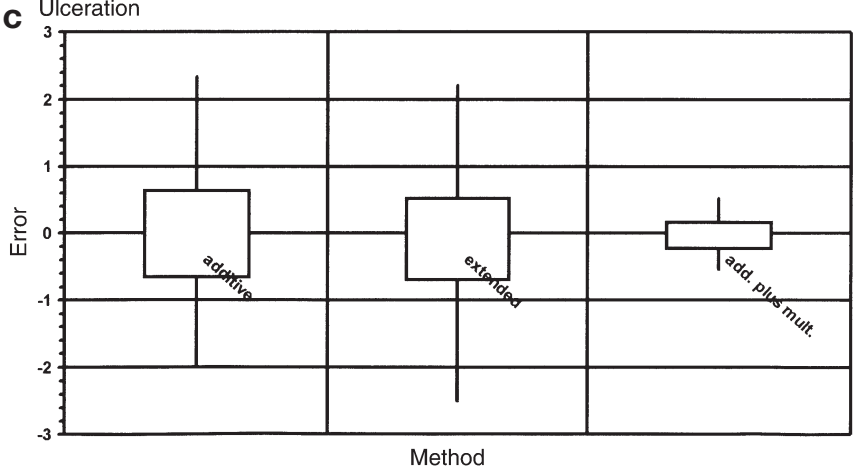

Fig. 2. Limanda limanda. Comparison of the variability resulting from the models: (a) lymphocystis, (b) epidermal hyperplasia/papilloma, and (c) skin ulceration 


\section{Disease and gender}

The average sex ratios obtained in the respective areas are contained in Table 2. Data relate to dab $>15 \mathrm{~cm}$. Two examples for the geographical distribution of sex ratios are given in Fig. 1 for the years 1992 and 1996. For the example in 1992 there were areas with equal sex ratios such as those around Stns N01, N11, N10, N07 and I20. In areas off the southern coast of Iceland males dominated. This was also true for areas around Stns N05 and N06 off the Scottish coast. At the Dogger (Stn N04) females predominated. In the second example from 1996 in Fig. 1b in the sampling areas in the Irish Sea (Stns E01 and E02) females dominated clearly as well as in areas north of there (Stns G02 and G04). Again, in the areas around Stns N05 and N06 off the Scottish coast males predominated. This was also the case at Stn G08 in the British Channel and Stn N03 off the Dutch coast.

There was a certain constancy over time in some of the areas, for example Stn G08 in the years 1994 to 1997, where males always dominated. For areas around Stns N05 and N06 off the Scottish coast the dominance of males was found during all cruises from 1992 to 1997.

In Fig. 3 the prevalence of lymphocystis, epidermal papilloma, and ulceration in dab $>15 \mathrm{~cm}$ is depicted separately for sexes, related to the numbers of males and females inspected. Apart from a certain constancy of the regional patterns in subsequent years, it becomes obvious that there is high regional variability of the ratios of males and females affected. The patterns obtained are not consistent; they vary from location to location and from year to year.

Results of a chi-square test on sex-related differences of average disease rates per year are to found in Table 4. For skin ulceration, no significant differences were observed. For hyperplasia/epidermal papilloma, the prevalence in males was significantly lower than that in females in 1992, 1994 and 1996. For lymphocystis, the prevalence in males was significantly higher in 1993 and 1995 through 1997.

\section{Lymphocystis}

The mean prevalence of lymphocystis as resulting from the application of the additive plus multiplicative model is displayed in Fig. 4. It appears that the mean prevalence rate was lower in the year 1994 and higher in the year 1995 (Fig. 4a). This is also to be found in Fig. $4 \mathrm{~b}$, where the years effect is displayed and a negative deviation for 1994 and a positive deviation for 1995 can be registered.

Fig. 4c contains comparisons of the mean prevalence rates for lymphocystis in all areas covered. The regional pattern obtained in Fig. 4c is also reflected in Fig. $4 \mathrm{~d}$, where the area effects are considered. Positive area effects can be observed for areas located in the northwestern sector of the North Sea (Fig. 4d). Prevalence rates in the areas in the south-eastern sector were lower. Positive deviations were also found in areas along the Icelandic south coast and northwest of Scotland.

Dab in areas in the Irish Sea and along the British Channel coast as well as off the west coast of Iceland were characterised by low rates of infection with lymphocystis.

\section{Epidermal hyperplasia/papilloma}

Mean prevalence of hyperplasia/epidermal papilloma is displayed in Fig. 5a. Differences in infection rates were slightly higher than the overall average in 1994 and lower in 1995. This is also reflected in Fig. 5b, where the year effects are displayed. Fig. 5c contains mean prevalence rates of epidermal hyperplasia/papilloma in the areas covered. The infection rate of dab from the station off the Icelandic west coast (I20) was lowest. The most prominent area effect is for Stn N01, and Stns G01, N04, N06, N07 and N11 also display positive effects (Fig. 5d). Negative deviations were found for areas off the south coast and west coast of Iceland (Stns I19, I20), and areas in the Irish Sea and off the British south coast.

Table 4. Limanda limanda. Infection rates by sex, total yearly averages, chi-square test for differences between males and females; significant differences in bold. $\Uparrow$ : infection rate in males significantly higher than in females; $\Downarrow$ : infection rate in males significantly lower than in females. Ly: lymphocystis; Ep: epidermal papilloma; Ulc: ulceration

\begin{tabular}{|c|c|c|c|c|c|c|c|c|c|c|}
\hline Year & Total n & Ly female & Ly male & $\mathrm{p}$ & Ep female & Ep male & $\mathrm{p}$ & Ulc female & Ulc male & $\mathrm{p}$ \\
\hline 1992 & 7785 & 16.41 & 17.50 & 0.215 & 4.28 & $2.97 \Downarrow$ & 0.0021 & 4.86 & 4.95 & 0.874 \\
\hline 1993 & 5612 & 15.66 & $19.49 \Uparrow$ & 0.0002 & 4.69 & 3.82 & 0.124 & 8.01 & 8.63 & 0.467 \\
\hline 1994 & 3922 & 10.07 & 11.81 & 0.102 & 5.47 & $3.21 \Downarrow$ & 0.0004 & 5.83 & 6.29 & 0.688 \\
\hline 1995 & 4387 & 11.33 & $15.10 \Uparrow$ & 0.0003 & 3.01 & 2.32 & 0.193 & 5.73 & 4.70 & 0.138 \\
\hline 1996 & 4143 & 8.51 & $13.05 \Uparrow$ & 0.0000 & 4.68 & 4.92 & 0.884 & 1.97 & 2.48 & 0.291 \\
\hline 1997 & 4321 & 9.19 & $13.23 \Uparrow$ & 0.0000 & 5.47 & $3.40 \Downarrow$ & 0.0016 & 5.01 & 5.87 & 0.179 \\
\hline
\end{tabular}


a

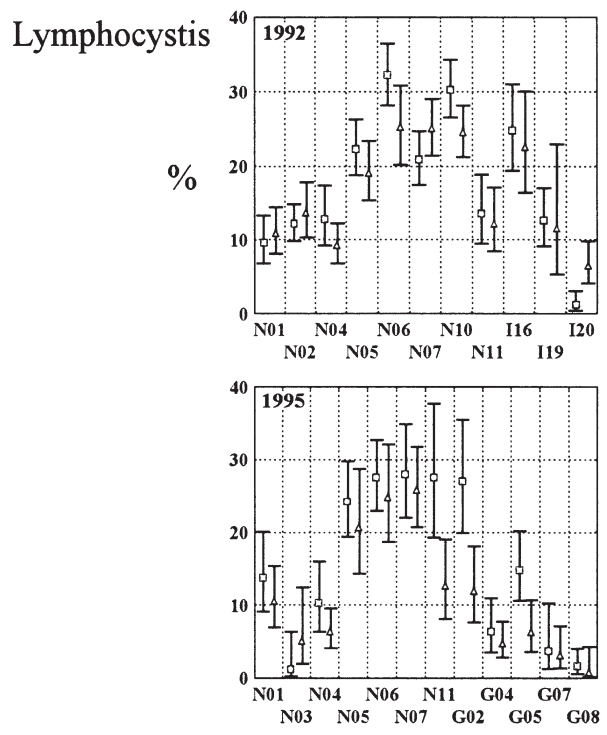

b Epidermal papilloma
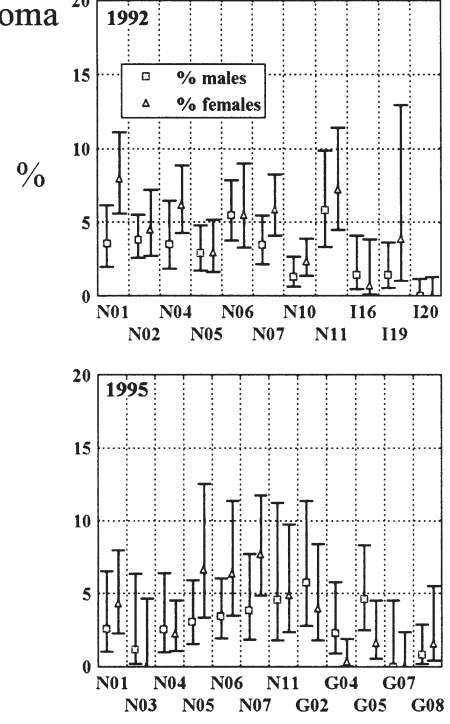

c

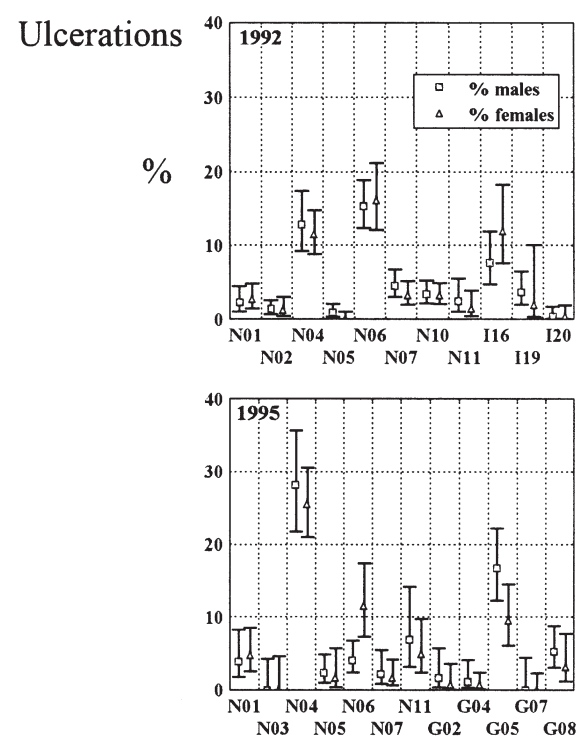

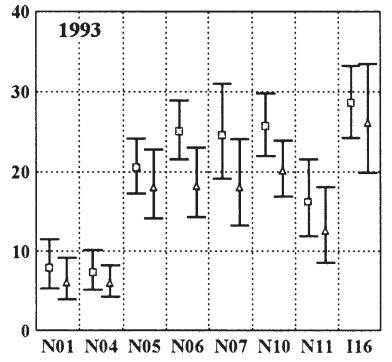
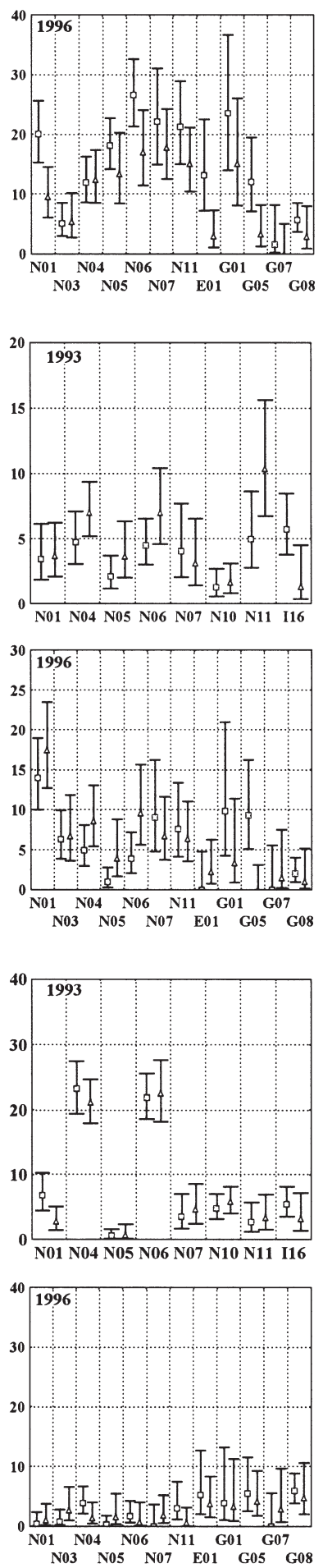
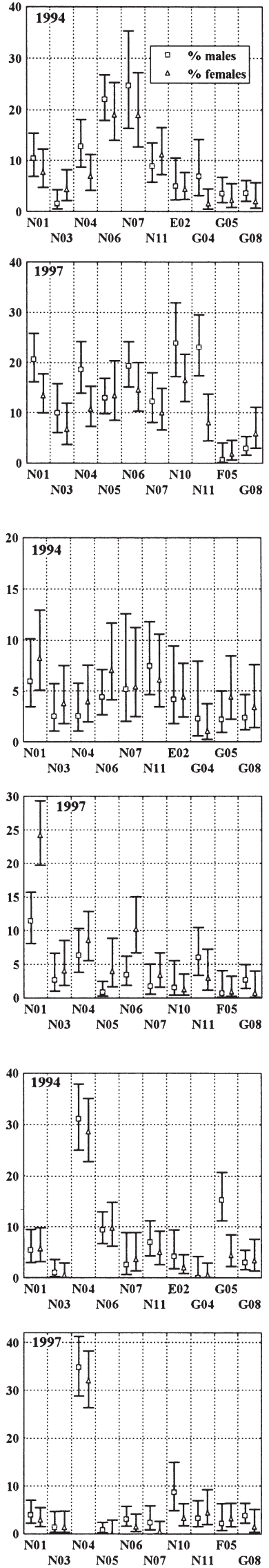

Fig. 3. Limanda limanda. Prevalence of (a) lymphocystis, (b) epidermal hyperplasia/papilloma, (c) skin ulceration, given separately for males and females 


\section{Lymphocystis}
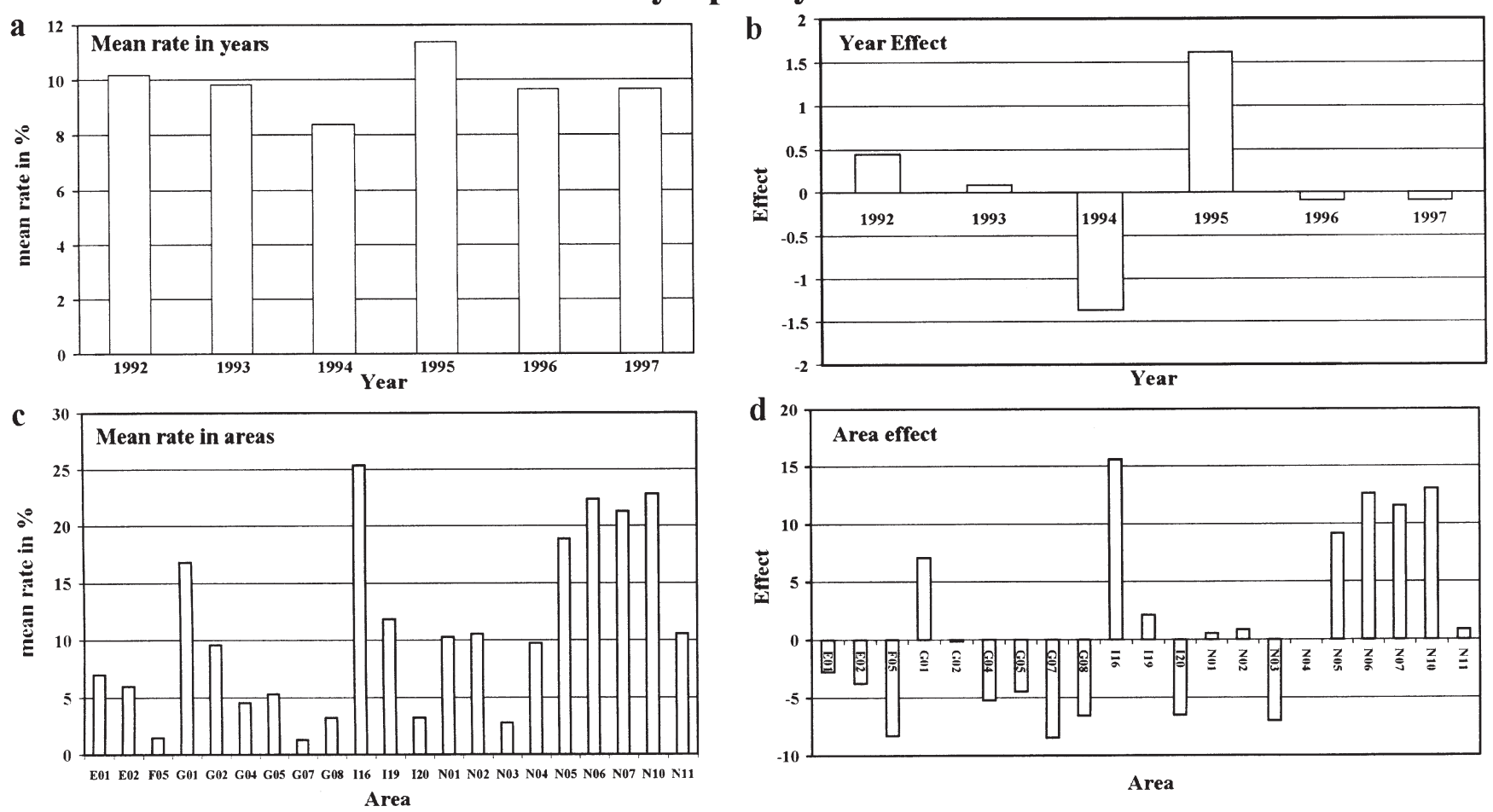

Fig. 4. Limanda limanda. Lymphocystis, additive plus multiplicative model. (a) \% mean annual prevalence, (b) mean year effects, (c) mean prevalence rates for areas, (d) area effect

\section{Epidermal Papilloma}
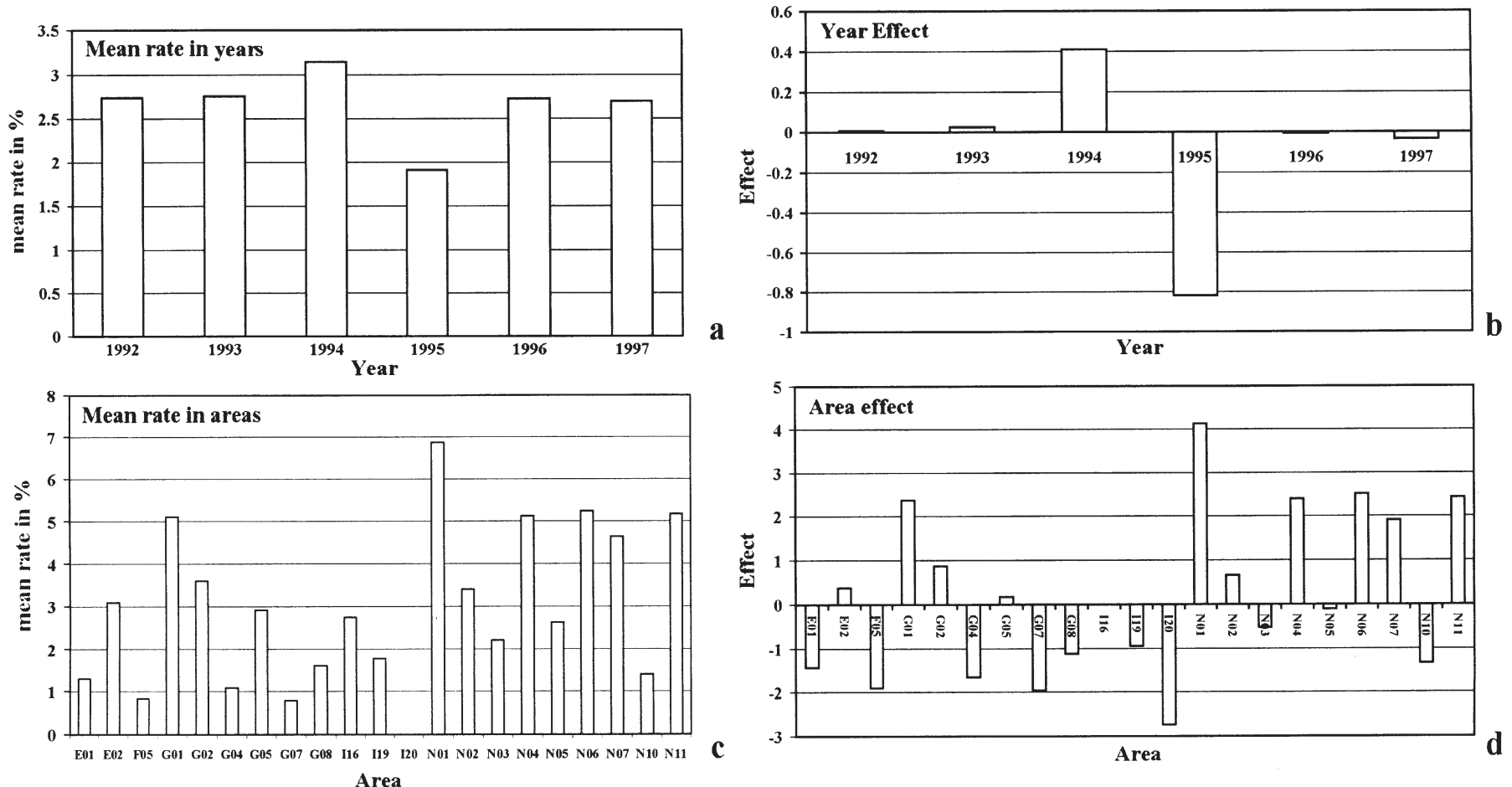

Fig. 5. Limanda limanda. Epidermal hyperplasia/papilloma, additive plus multiplicative model. (a) Mean annual infection in percent, (b) mean year effects, (c) mean prevalences for areas, (d) area effect 


\section{Skin ulceration}

Mean prevalence of skin ulceration for the respective years is given in Fig. 6a. A positive deviation from the total average can be observed for the year 1994; for year effects refer to Fig. 6b. All other year effects can be considered insignificant.

Regional comparison of mean prevalence of skin ulceration is found in Fig. 6c. The highest infection rates were detected in 2 areas (at Stn G05 = off Sellafield, Stn N04 = Dogger). For area effect see Fig. $6 \mathrm{~d}$.

\section{DISCUSSION}

\section{Disease and gender}

Published information on sex-related differences in prevalence rates of the diseases under study is contradictory. While Möller (1979) did not find differences for lymphocystis and van Banning (1987) did not expect sex-linked differences in his results, others like Wolthaus (1984a), Vethaak et al. (1992) and Mellergaard \& Nielsen (1997) found sex-related disease prevalence. The pattern emerging from the latter studies corre- sponds to our findings: lymphocystis is more frequent in females and epidermal papilloma are more frequent in males.

For ulceration, differences existed for some of the areas studied by Mellergaard \& Nielsen (1997) but were absent during our present study, a finding also published by Wolthaus $(1984 \mathrm{a}, \mathrm{b})$ for German Bight dab. There are no obvious explanations for these differences. It is not sufficient to assume that sex-specific differences in physiology, growth, contamination or migration patterns and timing are the only triggers. Additional factors relating to the etiology of each disease must also play a decisive role. When discussing regional differences of sex ratios, it should be kept in mind that in our case sampling was performed once a year in one season; thus the patterns reported are snapshots of a situation highly variable over space and time. Dab are known to perform migrations to and from spawning areas and feeding grounds with different arrival and departure times for males and females; females are suspected to cover longer distances than males (Wolthaus 1984a,b). In a pre-spawning situation female dab were shown to dominate in onshore areas of the German Bight. From July to September these females begin their migration into spawning grounds

\section{Ulceration}
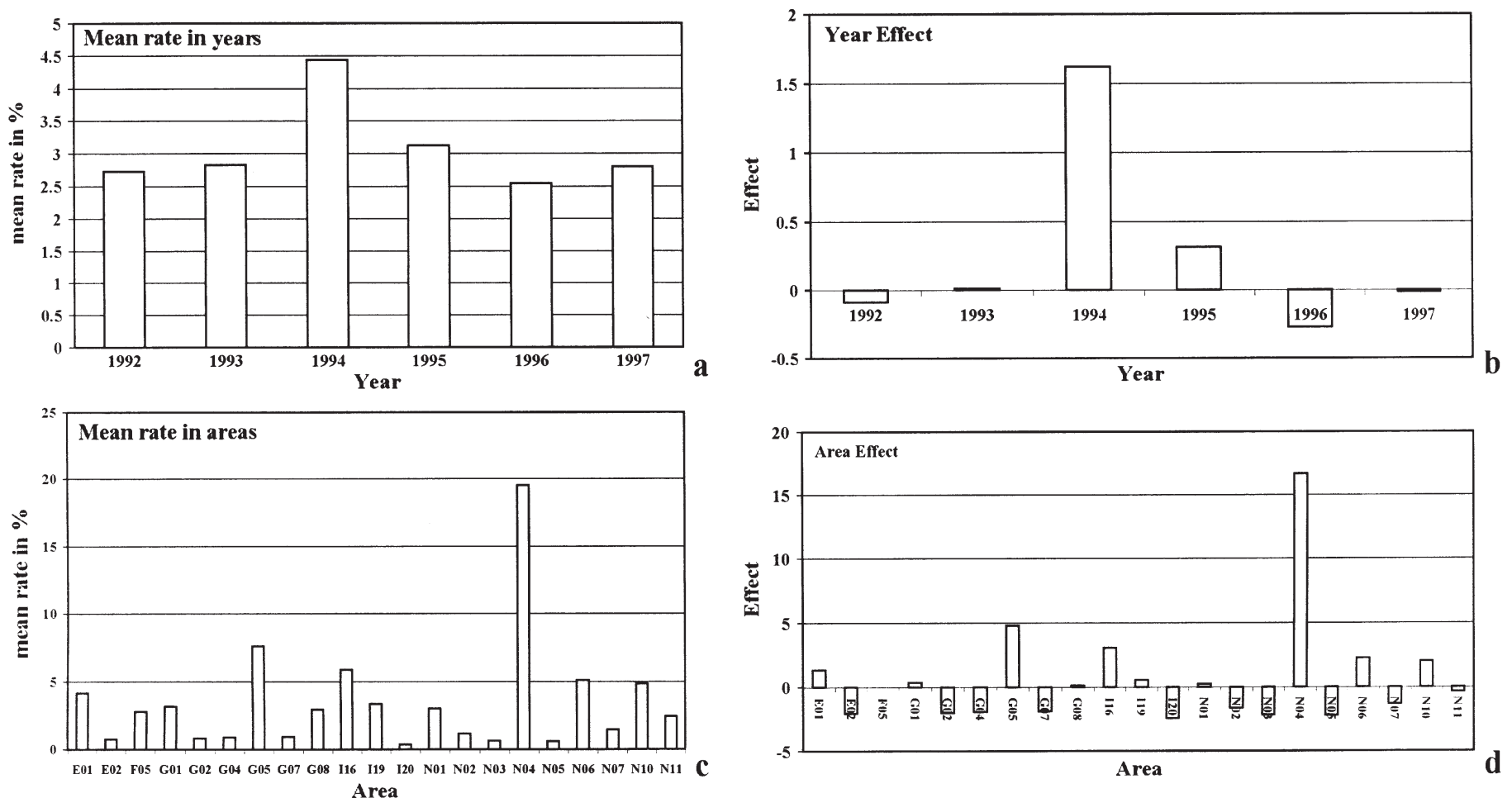

Fig. 6. Limanda limanda. Skin ulceration, additive plus multiplicative model. (a) \% mean annual prevalence, (b) mean year effects, (c) mean prevalence for areas, (d) area effect 
southwest and northwest of Helgoland, and sex ratios gradually change in the respective areas. On the other hand, Saborowski \& Buchholz (1997) state that during spring and summer the population structure of dab in the Helgoland area remains relatively constant. Although this finding might not be transferred to other areas during our study, at least for the German Bight it is a fair statement that our sampling time is the one which shows stable population structures for the longest possible period.

\section{Comparison of data on spatial distribution and prevalence with results from other authors}

For reasons mentioned in the introduction methodological differences in the determination of externally visible diseases may result in a certain variability of results from different authors (Dethlefsen et al. 1984). Möller (1988) states that improving skill may cause investigators to detect increasing disease levels over time in their long-term series. On the other hand, it is known that regional, seasonal and annual differences of prevalence may account for a high variability (Wolthaus 1984b, Dethlefsen et al. 1987, Mellergaard \& Nielsen 1997). Most of the authors of the preceding studies more or less concentrated their investigation on their territorial waters, but there are exceptions such as Möller (1979), van Banning (1987) and Dethlefsen (e.g. Dethlefsen et al. 1987), who studied wider areas of the North Sea.

\section{Lymphocystis}

Prevalence rates in the present paper corresponded to those reported by Mellergaard \& Nielsen (1997), who found between 4.5 and $12.8 \%$ infection in the German Bight between 1983 and 1992 (average in our study $10 \%$ ). Figures reported by van Banning (1987) and Möller (1979) were consistently lower. Van Banning (1987) covered North Sea stations east of $2^{\circ} \mathrm{E}$ and south of $57^{\circ} \mathrm{N}$ from 1981 to 1985 . Prevalence was lower in autumn than in spring and was between $1.1 \%$ (avg.) and up to $2.9 \%$ (max.) in 1982 and $4.5 \%$ (avg.) and $16.1 \%$ (max.) in 1984. Rates on and around the Dogger were between 6 and $>10 \%$. Möller (1979) in August 1978 covered North Sea stations within the area $52^{\circ} 40^{\prime} \mathrm{N}$ and $57^{\circ} 40^{\prime} \mathrm{N}$. The overall rate of dab with lymphocystis was $0.7 \%$ for winter and $2.5 \%$ for summer cruises. At a number of stations in the North Sea he found zero prevalence; in the German Bight prevalence was between 1 and $5 \%$, and at the Dogger and its vicinity between 5 and $21 \%$. Numbers given for Dutch and Irish waters were also at the lower end of our ranges (Perkins et al. 1972, Shelton \& Wilson 1973, Bucke et al. 1983b, Vethaak \& van der Meer 1991). In earlier studies, hot spots for the occurrence of lymphocystis in North Sea dab were the Dogger and the German Bight (Möller 1979, Dethlefsen et al. 1987).

The western Baltic has not been covered during this study, but it has been reported in the literature that prevalence of lymphocystis of dab in the Kiel Bight was comparable to that from dab of the German Bight but lower than in the North Sea proper (Dethlefsen \& Lang 1994).

\section{Epidermal hyperplasia/papilloma}

Möller (1979) did not find epidermal hyperplasia/papilloma on dab during early spring surveys in 1977 and 1978 in the North Sea. He detected the disease on $0.6 \%$ of the dab from the Dogger in August 1978. Perkins et al. (1972) and Shelton \& Wilson (1973) did not mention the occurrence of this disease on dab from the northeast Irish Sea. Bucke et al. (1983b) found 1.1\% of dab from Liverpool Bay to be afflicted with the disease. In their long-term study Mellergaard \& Nielsen (1997) found up to $9.4 \%$ of dab from the German Bight with epidermal hyperplasia/papilloma and up to $7.9 \%$ of dab from the Horns Reef area to be afflicted. Again, infection rates of dab in the Skagerrak area were significantly lower than in most of the other areas. Van Banning (1987) found the disease to have a higher prevalence in spring as compared to autumn, and Dethlefsen (1990) encountered up to $9.5 \%$ of dab from the German Bight and up to $14.0 \%$ of fish from the Dogger Bank which were afflicted with epidermal hyperplasia/papilloma. The overall prevalence in Dutch coastal waters in March and April 1986 to 1988 was $4.7 \%$ (Vethaak \& van der Meer 1991). In the literature for the respective areas ranges reported for this disease too were close to those found in our study. Regional hot spots were, according to van Banning (1987) and Mellergaard \& Nielsen (1997), the German Bight and adjacent areas and the Dogger (Dethlefsen 1990).

\section{Ulceration}

Möller (1979) found between 0 and $12 \%$ of dab afflicted with skin ulceration. The highest prevalence of dab with skin ulceration has been reported by Dethlefsen (1990), i.e. $25.0 \%$. All other authors found lower rates in the periods and areas studied. From Mellergaard \& Nielsen (1997) it becomes obvious that prevalence in dab from the Skagerrak area was lower as compared to prevalence in areas around Horns Reef and the German Bight. 
The overall prevalence of ulceration in Dutch coastal waters in March and April 1986 to 1988 was 0.6\% (Vethaak \& van der Meer 1991).

The wide range of prevalence is mainly produced by differences between areas, the Dogger (Stn N04) being the outstanding hot spot with a long-term high level of prevalence and relatively low fluctuations over time. Elevated levels of dab afflicted with ulceration were also found in the area around Stn G05 in the Irish Sea.

\section{Synopsis}

In our and most of the preceding studies lymphocystis was the most frequent externally visible disease of common dab Limanda limanda. The regional pattern produced during this study reveals that elevated disease levels were to be found in areas off the Scottish east and north coast as well as at Stn I16 at the southern coast of Iceland, where prevalence was highest during this study.

The early publications of Johnstone $(1922,1924)$ as well as a report published by Mann (1970) make it clear that elevated prevalence of this viral disease has persisted for a number of decades with no obvious continuous up- and downward trends (Dethlefsen 1990). Lymphocystis has been postulated to be associated with environmental factors (Sindermann 1996). This would mean that despite changing quality and composition of triggering stressors over time the resulting stress for the organism must have remained unchanged. Watermann \& Kranz (1992) state that lymphocystis from 1954 to today is enzootic in several areas (occurring in particular seasons and certain areas every year). During our study there were only 6 areas with mean rates less than 5\%. These were located in the Reykjavik Bight (Stn I20), off the west coast of Scotland (G04), in the English Channel (Stns G07, F05, G08), and off the Dutch coast (Stn N03). In areas not covered during our study lymphocystis was reported to occur on dab in the Kattegat (Mellergaard \& Nielsen 1997) and the western Baltic (Dethlefsen \& Lang 1994). Thus, it can be stated that lymphocystis is ubiquitous within the limits of the distribution of dab.

At present there is no answer to the question of what causes the long-term elevated levels of lymphocystis in the central North Sea, and off the Scottish north and west coast. It is safe to assume that in these diverse areas different stressors must exert an influence on the immune capabilities of dab.

The highest mean rates of epidermal papilloma were found in the German Bight. In the areas around Stns G01, N04, N06, N07 and N11 mean rates above $4 \%$ were detected. Mean rates below $1 \%$ were found in the English Channel (Stns F05 and G07) and in the Reykjavik Bight (Stn I20). Watermann \& Kranz (1992)

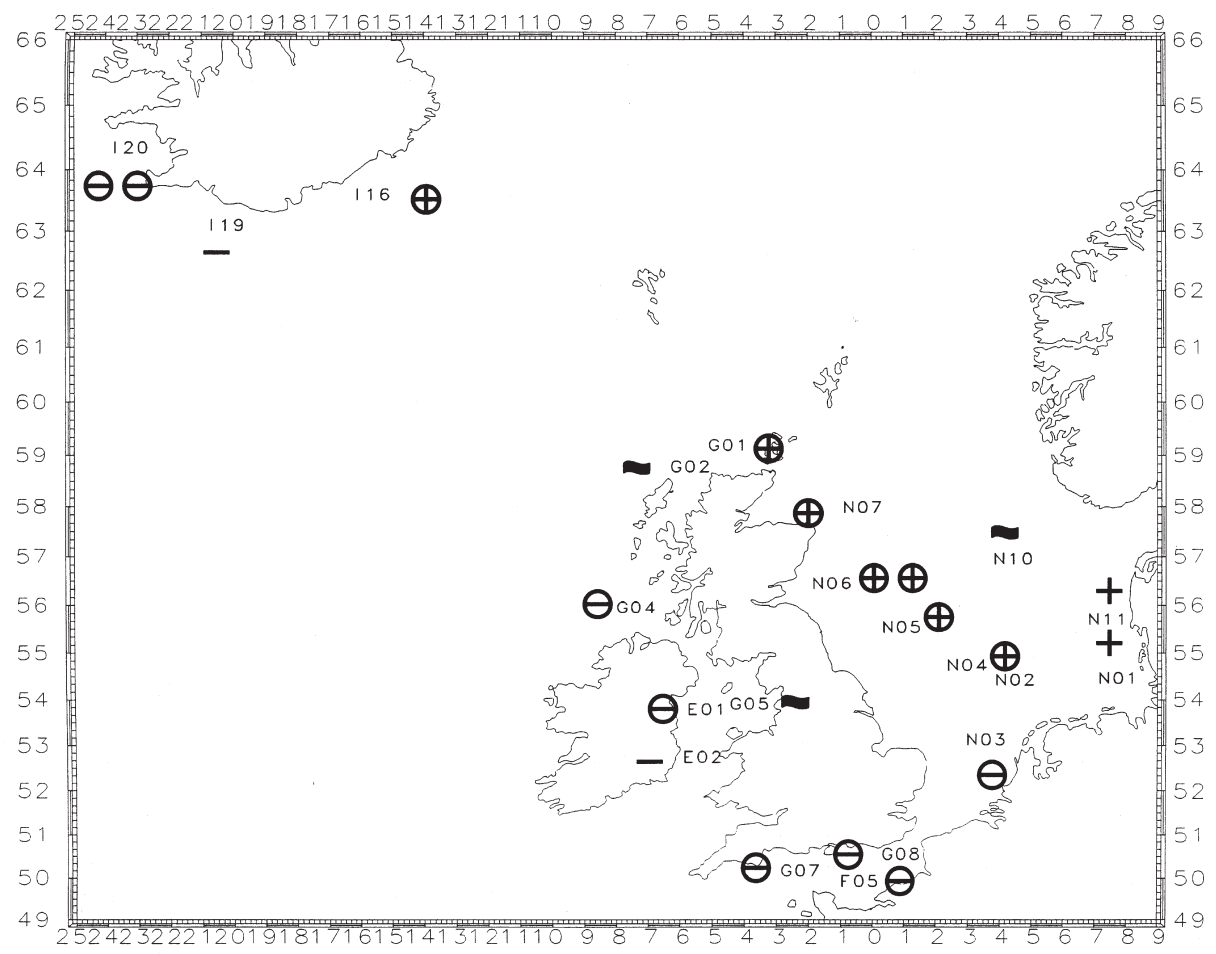

Fig. 7. Limanda limanda. Summary of area effects for prevalence of lymphocystis, epidermal papilloma and ulceration. ( $\oplus \oplus) 3$ diseases high, $(\boldsymbol{\oplus}) 2$ diseases high, $(+) 1$ disease high, $(\boldsymbol{\Theta}) 3$ diseases low, $(\boldsymbol{\Theta}) 2$ diseases low, $(-) 1$ disease low, $(\boldsymbol{\sim}) 1$ disease high, 1 low 
also state that this disease is enzootic in several areas of the North Sea. The main occurrence of epidermal papilloma according to the literature was the Dogger Bank and the German Bight. Based on preceding work (Dethlefsen et al. 1987) and the present study, it can be stated that in addition to the patterns mentioned by Watermann \& Kranz (1992) areas around the northeastern and northern stations of Scotland are characterised by consistently high mean rates of epidermal papilloma.

Prevalence of epidermal papilloma of dab of around $2.8 \%$ in the German Bight were first described in January 1980. In January 1986, 9.5\% of dab were found to be afflicted in the area used for dumping wastes from titanium dioxide production (Dethlefsen et al. 1987). These findings gave rise to a discussion whether components of the wastes dumped into an area $12 \mathrm{n}$ miles northwest of Helgoland could trigger the outbreak of this specific disease. The dumping was terminated at the end of 1989 and almost $10 \mathrm{yr}$ afterwards the level of this disease in the German Bight was higher than anywhere else during this study.

The area of elevated disease levels for epidermal papilloma was to a large degree similar to that identified for lymphocystis; exceptions were German Bight and Horns Reef (Stn N11). The mean rate of above $5 \%$ at the northern tip of Scotland (Stn G01) deserves special attention because the area was hitherto considered to be characterised by pristine waters. Epidermal papilloma were absent at Stn I20 in Icelandic coastal waters.

Ulceration has already been described by various authors to have the highest prevalence on dab from the Dogger. During all cruises we performed since 1980 dab from the Dogger were characterised by a high prevalence of ulceration in either the acute, healing or healed and scarred form. This fact indicates a certain local stability of the Dogger population. The question of whether this is brought about by the absence of seasonal migrations of dab in the area cannot be answered. It is interesting to note, though, that McVicar et al. (1988) found a reproducible sharp separation between dab affected with x-cell gills and healthy fish within a few miles of each other off the Scottish east coast. The stable patchiness in the occurrence of dab with $\mathrm{x}$-cell gill in studies in the North Sea (Knust \& Dethlefsen 1986) could either be interpreted as an indication of a greater local stability of dab in these areas as contrasted by the proven migrations of dab from the German Bight and the southern North Sea or reflects a different migratory behaviour of healthy and diseased dab.

The occurrence of elevated levels of ulceration off Sellafield (Stn G05, mean rates during our study $7.5 \%$ ) and at the Icelandic South coast (Stn I16 6.0\%) was hitherto unknown. Considering the pollutional status of the Iceland station, it is interesting to note unpublished results on heavy metals in sediments which were analysed in 1993 (Albrecht unpubl. data). Concentrations of $\mathrm{Hg}, \mathrm{Cd}, \mathrm{Zn}, \mathrm{Pb}, \mathrm{Cr}, \mathrm{V}$ and $\mathrm{Mn}$ were lower than in the German Bight, but those of $\mathrm{Cu}$ and Fe were higher at the Icelandic station; $\mathrm{Cu}=35.5 \mu \mathrm{g}$ $\mathrm{kg}^{-1}$ in the German Bight and $132.5 \mu \mathrm{g} \mathrm{kg}^{-1}$ related to the sediment fraction $<20 \mu \mathrm{m}$ at Stn I16; Fe $=8.5 \%$ (related to total sediment) in the German Bight and $11.2 \%$ at Stn I16 (Iceland).

A summary of the regional distribution of 3 major diseases of dab during our investigation is given in Fig. 7 . Stations were categorised based on the following prevalences: 3 diseases high, 2 diseases high, 1 disease high; 1 disease high, 1 low; 1, 2 or 3 diseases low. In the area in the Reykjavik Bight all diseases were low; this station might serve as reference for future comparisons.

A comprehensive discussion of possible reasons for the distribution patterns obtained is outside the scope of our study but it should be kept in mind that the occurrence of an infectious disease is always the result of an imbalance in the complex interplay between host, environment and infectious agent (Rolle \& Mayr 1978). This concept implies that a multitude of factors (not only pollutants) and their combinations trigger the outbreak of health disorders.

Given the improved availability of data on the pollution and hydrography of the areas under survey and the good knowledge on diseases of certain indicator fish species, it now seems to be appropriate to synthesise the information on possible biological effects of anthropogenic activities. Approaches should take into account the complexity of multiple interactions and could provide a better basis for our understanding of reasons for the occurrence of long-term elevated disease levels in the North Sea and adjacent areas.

Acknowledgements. Thanks are due to captains and crew of 'Walther Herwig II' and 'Walther Herwig III', to Ursula Kürschner, Thomas Tepperies, Barbara Eggeling and Lore Rennert for technical assistance and to Ulrich Damm, Werner Wosniok and Dick Vethaak for critically reading the manuscript.

\section{LITERATURE CITED}

Anonymous (1989) Methodology of fish disease survey. Report on an ICES sea-going workshop held on U/F ARGOS 16-23 April 1988. ICES Coop Res Rep 166:1-33

Bucke D, Norton MG, Rolfe MS (1983a) The field assessment of effects of dumping wastes at sea: II. Epidermal lesions and abnormalities of fish in the outer Thames Estuary. Fish Res Tech Rep 72:1-16

Bucke D, Feist S, Rolfe MS (1983b) Fish disease studies in Liverpool Bay and the North Irish Sea. ICES CM 1983 E:5, $1-8$

Bucke D, Vethaak AD, Lang T, Mellergaard S (1996) Common diseases and parasites of fish in the North Atlantic: training guide for identification. ICES Tech Mar Environ Sci 19:1-27 
Dethlefsen V (1980) Observations on fish diseases in the German Bight and their possible relation to pollution. Rapp PV Réun Cons Int Explor Mer 179:110-117

Dethlefsen V (1984) Diseases in North Sea fishes. Helgol Meeresunters 37:353-374

Dethlefsen V (1985) Krankheiten von Nordseefischen als Ausdruck der Gewässerbelastung. Abh Naturw Ver Bremen 40:233-252

Dethlefsen V (1986) Überblick über Auswirkungen der Verklappung von Abfällen aus der Titandioxidproduktion in der Deutschen Bucht. Veröff Inst Küsten- u Binnenfisch Hamburg 95:1-42

Dethlefsen V (1988) Status report on aquatic pollution problems in Europe. Aquat Toxicol 11:259-286

Dethlefsen V (1990) Ten years fish disease studies of the Institut für Küsten- und Binnenfischerei. Arch Fischwiss 40: $119-132$

Dethlefsen V, Lang T (1994) Fischkrankheiten in der Ostsee. Inf Fischw 41(2):92-101

Dethlefsen V, Watermann B, Hoppenheit M (1984) Sources of variance in data from fish disease surveys. Arch Fischwiss 34:155-173

Dethlefsen V, Egidius E, McVicar AH (1986) Methodology of fish disease surveys. ICES Coop Res Rep 140:1-33

Dethlefsen V, Watermann B, Hoppenheit M (1987) Diseases of North Sea dab (Limanda limanda L.) in relation to biological and chemical parameters. Arch Fischwiss 37: 107-237

Emerson JD, Wong GY (1985) Resistant nonadditive fits for two-way tables. In: Hoaglin DC, Mosteller F, Tukey JW (eds) 1985. Exploring data tables, trends and shapes. Wiley, New York, p 67-124

Hill BJ (1984) Lymphocystis disease of fish. ICES Fiche 2:1-5

Hoaglin DC, Mosteller F, Tukey JW (eds) (1985) Exploring data tables, trends and shapes. Wiley, New York, p 527

Johnstone J (1922) Diseases and parasites of fishes. Proc Trans Liverpool Biol Soc 36:286-301

Knust R, Dethlefsen V (1986) X-cells in gills of North Sea dab (Limanda limanda L.), epizootiology and impact on condition. Arch Fischwiss 37(1-2):11-24

Lang T, Mellergaard S (1999) The BMB/ICES sea-going workshop, fish diseases and parasites in the Baltic Sea-introduction and conclusions. ICES J Mar Sci 56:129-133

Lozàn JL (1988) Verbreitung, Dichte und Struktur der Population der Kliesche (Limanda limanda L.) in der Nordsee mit Vergleichen zu den Populationen um Island und in der Ostsee anhand meristischer Merkmale. Arch Fischwiss 38: 165-189

Lundbeck J (1955) Fischkunde für Jedermann. Praxis der Fischwirtschaft 1. Keune, Hamburg

Mann H (1970) Über den Befall der Plattfische der Nordsee mit Lymphocystis. Ber Dtsch Wiss Komm Meeresforsch 21: 219-223

McIntosh WC (1884) Multiple tumours in plaice and common flounders. Rep Fish Bd Scotl 214-215

McVicar AH, Bruno DW, Fraser CO (1988) Fish diseases in the North Sea in relation to sewage sludge dumping. Mar Pollut Bull 19:169-173

Mellergaard S, Nielsen E (1984) Preliminary investigations on the eastern North Sea and the Skagerrak dab (Limanda limanda) populations and their diseases. ICES $\mathrm{CM} / \mathrm{E}: 28$

Mellergaard S, Nielsen E (1997) Epidemiology of lymphocystis, epidermal papilloma and skin ulcers in common dab
Limanda limanda along the west coast of Denmark. Dis Aquat Org 30:151-163

Möller H (1979) Geographical distribution of fish diseases in the NE Atlantic. A bibliographic review. Meeresforschung $27: 217-235$

Möller H (1981) Fish diseases in German and Danish waters in summer, 1980. Meeresforschung 29:1-16

Möller H (1988) The problem of quantifying long-term changes in the prevalence of tumours and non specific growths in fish. J Cons Int Explor Mer 45:33-38

Perkins EJ, Gilchrist JRS, Abbott OJ (1972) Incidence of epidermal lesions in fish of the North-East Irish Sea area, 1971. Nature 238:101-103

Rijnsdorp AD, Vethaak AD, van Leuwen PI (1992) Population biology of dab Limanda limanda in the southern North Sea. Mar Ecol Prog Ser 91:19-35

Rolle M, Mayr A (1978) Mikrobiologie, Infektions- und Seuchenlehre für Tierärzte, Biologen und Agrarwissenschaftler, 4th edn. Enke, Stuttgart

Rühmer K (1954) Fische und Nutztiere des Meeres. Fischereiverlag Ebenhausen, München

Saborowski R, Buchholz F (1997) Some observations on the seasonal distribution of dab, Limanda limanda, in the southern North Sea. Helgol Meeresunters 51:41-51

Schäperclaus W (1927) Die Lymphocystiserkrankung bei Flundern und Schollen und ihre Bekämpfung. Mitt Dtsch Seefisch Ver 43:96-99

Shelton RGJ, Wilson KW (1973) On the incidence of dermal lesions in the flatfish stocks of the North-East Irish Sea. Proc Challenger Soc IV:5

Sindermann CJ (1996) Ocean pollution. Effects on living resources and humans. CRC Press, Boca Raton, FL, p 1-275

Tukey JW (1977) Exploratory data analysis. Addison-Wesley, Reading, MA

van Banning P (1987) Long-term recording of some fish diseases using general fishery research surveys in the southeast part of the North Sea. Dis Aquat Org 3:1-11

Vethaak AD (1985) Prevalence of fish diseases with reference to pollution of Dutch coastal waters. Neth Inst Fish Invest, Ijmuiden Rep CA 85-01:1-70

Vethaak AD, ap Rheinallt T (1992) Fish disease as a monitor for marine pollution: the case of the North Sea. Rev Fish Biol Fish 2:1-32

Vethaak AD, van der Meer J (1991) Fish disease monitoring in the Dutch part of the North Sea in relation to the dumping of waste from titanium dioxide production. Chem Ecol 5: $149-170$

Vethaak AD, Bucke D, Lang T, Wester PW, Jol J, Carr M (1992) Fish disease monitoring along a pollution transect: a case study using dab Limanda limanda in the German Bight. Mar Ecol Prog Ser 91:173-192

Watermann B, Kranz H (1992) Pollution and fish diseases in the North Sea. Some historical aspects. Mar Pollut Bull 24/3:131-13

Watermann B, Dethlefsen V, Mellergaard S (1987) Epidermal papilloma of dab. ICES Leaflet 33:1-3

Wolthaus BG (1984a) Populationsdynamik der Kliesche (Limanda limanda L.) und jahreszeitlicher Verlauf von Krankheitsbefallsraten mit Lymphocystis, epidermalen Papillomen, Geschwüren und Flossenfäule in der Deutschen Bucht. Dissertation, Universität Bremen

Wolthaus BG (1984b) Seasonal changes in frequency of diseases in dab, Limanda limanda, from the southern North Sea. Helgol Meeresunters 37(1-4):375-387

Submitted: June 10, 1999; Accepted: March 16, 2000

Proofs received from author(s): August 14, 2000 